AT - TADBIR

JURNAL ILMIAH MANAJEMEN

Homepage: ojs.uniska.ac.id/attadbir

\title{
Pengaruh Strategi Promosi Dan Harga Terhadap Keputusan Pembelian Yang Dimediasi Oleh Minat Beli Kain Sasirangan Bordir
}

\author{
Periyadi*1 $^{\text {, Junaidi }}{ }^{2}$, Noorlaily Maulida ${ }^{3}$ \\ 1,2,3 Fakultas Ekonomi, Universitas Islam Kalimantan MAB \\ Jl. Adhyaksa No. 2, Kayutangi Banjarmasin \\ e-mail: periyadi401@gmail.com
}

\begin{abstract}
The main objective of this research is to examine and analyze how much promotion strategy and price influence purchasing decisions mediated by buying interest in embroidery sasirangan fabrics. The method used in this research is quantitative research with a formal research procedure design that contains clear definitions of research objectives and information needs. To answer and achieve the research objectives, regression analysis will be used. The object of this research is the consumer or potential consumer of the Sasirangan Embroidered cloth "Bunga Bangkal Sasirangan" in the Bangkal Cempaka Village, Banjarbaru, South Kalimantan. From the research results, it is known that the promotion strategy directly affects the buying interest of Sasirangan cloth, while the price does not have a significant effect. The ability of the purchase intention variable as a mediator shows that the purchase intention variable can only mediate the effect of promotional strategies on purchasing decisions
\end{abstract}

Keywords: Promotion Strategy, Price, Purchase Decision, Buying Interest.

\begin{abstract}
Abstrak
Tujuan utama dalam penelitian ini adalah untuk mengkaji dan menganalisis seberapa besar strategi promosi dan harga mempengaruhi keputusan pembelian yang dimediasi oleh minat beli kain sasirangan bordir. Metode yang digunakan penelitian ini adalah penelitian kuantitatif dengan desain prosedur penelitian formal yang berisi definisi yang jelas dari sasaran penelitian dan kebutuhan informasi. Untuk menjawab dan mencapai tujuan penelitian tersebut, maka akan digunakan analisis regresi. Objek dalam penelitian ini adalah konsumen atau calon konsumen kain Sasirangan Bordir "Bunga Bangkal Sasirangan" di kelurahan Bangkal Cempaka Banjarbaru Kalimantan Selatan. Dari hasil Penelitian diketahui bahwa secara langsung, strategi promosi dapat berpengaruh terhadap Minat beli kain sasirangan, sedangkan harga tidak berpengaruh signifikan. Kemampuan variabel minat beli sebagai mediator menunjukkan bahwa variabel minat beli hanya dapat memediasi pengaruh strategi promosi terhadap keputusan pembelian
\end{abstract}

Kata Kunci : Strategi Promosi, Harga, Keputusan Pembelian, Minat Beli 


\section{PENDAHULUAN}

Pada era industri globalisasi yang semakin ketat di mana perdagangan yang bersifat bebas telah menjadi suatu fenomena yang harus dihadapi dengan persiapan yang matang dari berbagai macam faktor prooduksi yang dimiliki perusahaan. Tentunya pengaruh perdagangan bebas kini sudah sulit dibendung, semua Negara di dunia akan merasa dampaknya secara menyeluruh, untuk itu perusahaan harus dipersiapkan sebaik mungkin agar tidak tergilas pengaruh perkembangan arus globalisasi. Untuk itu, ujung tombak perusahaan yaitu pemasaran harus dipersiapkan dengan baik dan tepat waktu demi tercapainya target pasar yang telah ditetapkan dengan menghindari sekecil mungkin hal-hal yang infesiensi atau yang kurang menguntungkan bagi setiap perusahaan..

Kain sasirangan sebagai hasil budaya masyarakat Banjar merupakan sebuah kebanggan dan menjadi ciri khas masyarakat Banjar. Kain sasirangan sekarang ini sudah mengalami banyak perubahan. Dahulu para pengrajin kain sasirangan hanya menggunakan cara tradisional, alat yang tradisional bahkan bahan pembuataanya masih menggunakan bahan tradisonal dengan memanfaatkan bahan alam yang terdapat di lingkungan sekitar. Maka sekarang ini banyak menggunakan teknologi dan proses yang lebih modern namun, terdapat satu hal yang sampai saat ini masih bertahan, yaitu motif kain sasirangan. Motif pada kain sasirangan menjadi salah satu ciri khusus pada kain ini, hingga bertahan dan masih disukai masyarakat Banjar sampai sekarang. Motif pada kain sasirangan diadopsi dari lingkungan alam sekitar khususnya di Kalimantan Selatan.

Seiring dengan perkembangannya, kain sasirangan banyak mengalami perubahan dengan tujuan untuk meningkatkan penjualan yang lebih besar lagi daripada pendapatan pelaku home industry. Keadaan seperti inilah yang pada akhirnya menyebabkan para pelaku usaha home industry makin gencar melakukan berbagai macam usaha untuk mencari solusi maupun program bisnis yang dapat meningkatkan daya saing dalam bisnis yang mereka jalankan meskipun para pelaku usaha home industry telah berusaha bersaing dan memberikan yang terbaik untuk setaip konsumen belum tentu dapat menjamin akan berhasilnya usaha pencapaian tujuan usaha mereka. Sering kali para pelaku usaha home industry mendapatkan masalah dalam hal melakukan promosi, di mana secara garis besar konsumen hanya melihat harga yang ditawarkan sehingga hal tersebut dapat mempengaruhi minat beli konsumen.

Kain Sasirangan merupakan salah satu kain khas tradisional Suku Banjar dari Provinsi Kalimantan Selatan. Kain sasirangan sampai saat ini masih diproduksi oleh Masyarakat Banjar dalam skala industri rumahan (home industry). Namun pada perkembangannya batik sasirangan banyak mengalami perubahan salah satunya dengan batik sasirangan yang dibordir dan ternyata hal ini dapat diterima oleh khalayak banyak khususnya masyarakat Banjarbaru Kalimantan selatan. Kegiatan home industry Sasirangan bordir di Banjarbaru dengan produk berupa kain batik sasirangan bordir saat ini merupakan ikon Kota Banjarbari Provinsi Kalimantan Selatan.

Kegiatan promosi bagi banyak perusahaan merupakan kegiatan investasi yang sangat kritis melalui kegiatan pemasaran. Tanpa promosi maka konsumen akan sulit untuk mengetahui produk yang dijual oleh perusahaan (Freddy Rangkuti. 2002:1).

Strategi pelaksanaan promosi merupakan langkah-langkah yang secara berurutan dari awal sampai akhir dalam proses mempromosikan suatu produk, yaitu melalui 
periklanan yang kemudian diikuti dengan kegiatan promosi lainnya, diantaranya personal selling, promosi penjualan, dan publisitas.

Promosi dipandang sebagai kegiatan komunikasi pembeli dan penjual dan merupakan kegiatan yang membantu dalam pengambilan keputusan dibidang pemasaran serta mengarahkan dan menyadarkan semua pihak untuk berbuat lebih baik. Swastha (2001) Promosi yang tepat akan meningkatkan minat beli konsumen. Demikian pula penetapan harga yang sesuai dengan segmentasi dan sasaran pasar yang dituju. Para pelaku usaha home industry perlu melakukan aktifitas promosi yang tepat dan penetapan harga yang sesuai, sehingga mampu menarik minat beli konsumen. Minat beli yang ditindaklanjuti akan menjadi keputusan pembelian.

\section{Kajian Pustaka}

Pemasaran

Kasmir dan Jakfar (2003 : 74) mengemukakan bahwa pemasaran adalah suatu proses sosial dan manajerial dengan mana individu dan kelompok memperoleh apa yang mereka butuhkan dan inginkan dengan cara menciptakan serta mempertukarkan produk dan nilai dengan pihak lain. Tjiptono (2005:2) mengemukakan bahwa pemasaran merupakan proses dimana struktur permintaan terhadap produk dan jasa diantisipasi atau diperluas dan dipuaskan melalui konsepsi, promosi, distribusi, dan pertukaran barang. Pemasaran adalah suatu proses yang diterapkan perusahaan untuk memenuhi kebutuhan dan keinginan konsumen dengan menyediakan produk (barang dan jasa). Konsumen tertentu yang merupakan sasaran upaya pemasaran disebut pasar sasaran ( Machfoedz, 2010 : 140).

\section{Tujuan Pemasaran}

Tujuan pemasaran adalah mengenal dan memahami pelanggan sedemikian rupa, sehingga produk cocok dengannya dan dapat dijual dengan sendirinya, idealnya, pemasaran menyebabkan pelangan siap membeli, sehingga produsen harus berusaha agar produknya tetap tersedia.

Menurut Philip Kotler (2007:6) Tujuan pemasaran adalah menghasilkan standar hidup yang lebih tinggi agar konsumen memperoleh apa yang mereka butuhkan dan inginkan melalui penciptaan, menawarkan dan secara bebas mempertukarkan produk yang bernilai dengan pihak lain.

Suatu perusahaan yang menginginkan laba yang maksimal, maka biasanya perusahaan menggunakan dua cara, yaitu :

a. Penjualan yang dilakukan secara langsung kepada konsumen

b. Penjualan yang dilakukan dengan menggunakan perantara.

\section{Promosi}

\section{Pengertian Promosi}

Promosi penjualan adalah insentif yang cepat atau lambat menngerakkan orang untuk membeli atau mendapatkan, umumnya dalam jangka waktu pendek, baik dalam bentuk uang maupun barang sebuah produk atau jasa. Promosi pada hakekatnya adalah suatu komunikasi pemasaran, artinya aktifitas pemasaran yang berusaha menyebarkan informasi, mempengaruhi/membujuk, dan atau mengingatkan pasar sasaran atas perusahaan dan produknya agar bersedia menerima, membeli dan loyal pada produk yang ditawarkan perusahaan yang bersangkutan, Tjiptono (2001: 219).

Sistaningrum (2002 : 98) mengungkapkan arti promosi adalah suatu upaya atau kegiatan perusahaan dalam mempengaruhi "konsumen aktual" maupun "konsumen potensial" agar mereka mau melakukan pembelian terhadap produk yang ditawarkan, saat ini atau dimasa yang akan datang. Konsumen aktual adalah konsumen yang langsung membeli produk yang ditawarkan pada saat atau sesaat setelah promosi produk tersebut dilancarkan perusahaan.

\section{Tujuan Promosi}

Tujuan utama dari promosi yang akan dilakukan oleh perusahaan secara mendasar terdiri dari beberapa alternatif, antara lain: 
menginformasikan,

mempengaruhi, membujuk dan mengingatkan sasaran konsumen tentang perusahaan dan bauran pemasarannya. Menurut Subagyo (2010 : 133) dapat diuraikan sebagai berikut :

a. Menginformasikan

Sebagai tujuan utama dari kegiatan promosi yang akan dilakukan adalah menginformasikan seluruh aspek-aspek dan kepentingan perusahaan yang berhubungan dengan konsumen dapat dilakukan dengan sebaik-baiknya untuk dapat diketahui secara jelas. Mempengaruhi dan membujuk pelanggan sasaran

Sebagai alternatif kedua dari tujuan promosi yang akan dilakukan oleh perusahaan adalah mempengaruhi dan membujuk pelanggan atau konsumen sasaran agar mau membeli atau mengalihkan pembelian terhadap produkproduk yang dihasilkan perusahaan.

b. Mengingatkan kembali konsumen sasaran.

Sebagai alternative terakhir dari tujuan promosi yang akan dilakukan perusahaan adalah mengingatkan kembali konsumen sasaran yang selama ini dimiliki atas keberadaan perusahaan dan merek-merek produk yang dihasilkan yang tetap setia dan konsisten untuk melayani konsumennya dimanapun mereka berada.

3. Jenis Promosi

Ada empat jenis kegiatan promosi, antara lain Menurut (Kotler, 2001:98-100), yakni:

a. Periklanan (Advertising)

b. Penjualan Tatap Muka (Personal Selling)

c. Publisitas (Publisity)

d. Promosi Penjualan (Sales promotion)

e. Pemasaran Langsung (Direct marketing)

\section{Harga}

Menurut Stanton (2004:306) harga pasar sebuah produk mempengaruhi upah, sewa, bunga, dan laba. Artinya, harga produk mempengaruhi biaya faktor-faktor produksi (tenaga kerja, tanah, modal, dan kewiraswastaan. Sehingga definisi harga adalah alat pengukur dasar sebuah sistem ekonomi karena harga mempengaruhi alokasi faktor-faktor produksi. Dan harga juga dapat didefinisikan sebagai jumlah uang yang dibutuhkan untuk memperoleh beberapa kombinasi sebuah produk dan pelayanan yang menyertainya. Dalam menghadapi persaingan, perusahaan perlu lebih bijaksana dalam menentukan harga produknya. Banyak hal-hal yang harus dipertimbangkan oleh pengusaha sebelum menetapkan harga suatu produk.

\section{Keputusan Pembelian}

Menurut Sciffman dan Kanuk (dalam Sumarwan, 2004: 289,292), suatu keputusan merupakan pemilihan suatu tindakan dari dua atau lebih pilihan alternatif. Seorang konsumen yang hendak melakukan pilihan maka ia harus memiliki pilihan alternatif. Ada tiga tipe pengambilan keputusan konsumen:

a. Pemecahan masalah yang diperluas (extensive problem solving)

b. Pemecahan masalah terbatas (limited problem solving)

c. Pemecahan masalah rutin (routinized response behavior).

\section{Minat Beli}

Menurut Kotler dan Keller (2003: 186), the consumer may also form an intention to buy the most preffered brand yang berarti bahwa konsumen mempunyai keinginan untuk membeli suatu produk berdasarkan pada sebuah merek. Minat beli timbul setelah adanya proses evaluasi alternatif dan di dalam proses evaluasi, seseorang akan membuat suatu rangkaian pilihan mengenai produk yang hendak dibeli atas dasar merek maupun minat (Kotler, Bowen, \& Makens 1999: 156).

Swastha \& Irawan (2001) mengemukakan faktor-faktor yang mempengaruhi minat membeli yang berhubung dengan perasaan dan emosi, bila seseorang merasa senang dan puas dalam membeli barang atau jasa maka hal itu akan memperkuat minat membeli, ketidakpuasan biasanya menghilangkan minat. 


\section{Prilaku Konsumen}

Menurut Mowen (2002) bahwa, "perilaku konsumen (consumer behaviour) didefinisikan sebagai studi tentang unit pembelian (buying units) dan proses pertukaran yang melibatkan perolehan, konsumsi dan pembuangan barang, jasa, pengalaman serta ide-ide.

Sedangkan menurut Kotler (2007) bahwa, "perilaku konsumen merupakan studi tentang cara individu, kelompok, dan organisasi menyeleksi, membeli, menggunakan, dan memposisikan barang, jasa, gagasan, atau pengalaman untuk memuaskan kebutuhan dan keinginan mereka”.

Peter dan Olson (1999) dalam

Simamora (2003) menyatakan bahwa perilaku konsumen adalah soal keputusan. Lebih jauh lagi, keputusan adalah soal pilihan. Untuk lebih jelasnya mereka menyatakan bahwa keputusan meliputi suatu pilihan "antara dua atau lebih alternatif tindakan atau perilaku".

Sastradipora (2003) menyatakan bahwa: "perilaku konsumen adalah proses dimana para individu menetapkan jawaban atas pertanyaan: perlukah, apakah, kapankah, dimanakah, bagaimanakah, dan dari siapakah membeli barang atau jasa".

Berdasarkan penjelasan diatas, maka konsep/kerangka pikir dalam penelitian adalah sebagai berikut:

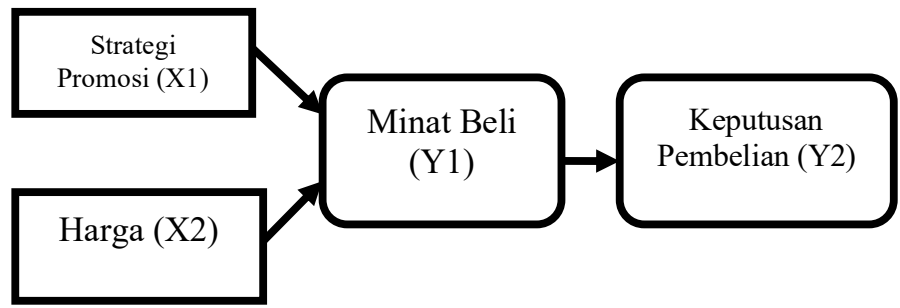

Gambar 1. Kerangka Penelitian

Sumber: Data diolah, 2020

\section{METODE PENELITIAN}

Jenis \& Lokasi Penelitian

Penelitian ini bersifat penelitian kuantitatif. Desain penelitiannya dengan prosedur penelitian formal yang berisi tentang beberapa definisi yang jelas dari sasaran dalam penelitian dan kebutuhan akan adanya informasi.

\section{Populasi dan Sampel Penelitian}

Adapun jumlah sampel dalam penelitian diambil sebanyak 100 responden dengan teknik Acidental Random.

\section{Metode Analisis Data}

Teknik analisis data yang digunakan dalam penelitian ini adalah teknik regresi linear berganda dengan pendekatan Path Analysis. Sebelum dilakukan pengujian dengan analisis regresi, data penelitian diuji dengan uji asumsi klasik yang terdiri dari : uji normalitas, uji heterokedastisitas, dan uji multikolonieritas.

\section{HASIL DAN PEMBAHASAN}

\section{Hasil}

Hasil pernyataan responden dan perhitungan nilai rata-rata pernyataan responden disetiap item pertanyaan variabel Strategi Promosi dapat dilihat pada tabel 1.

Tabel 1 menunjukan bahwa, jawaban responden mengenai Iklan sasirangan Bordir Dimedia Massa dan elektronik berada pada skor jawaban 4,16 yang terletak antara rentang 3,40-4,19 yang menunjukan bahwa pernyataan nomor 1 termasuk dalam kategori baik. Jawaban responden mengenai iklan mampu menjangkau semua kalangan berada pada skor jawaban 4,56 yang terletak 
antara rentang 4,20 - 5,00 menunjukan bahwa pernyataan nomor 2 termasuk dalam kategori sangat baik. Sedangkan jawaban responden mengenai iklan yang dipromosikan sesuai dengan kualitas produk yang dijual berada pada skor jawaban 4,32 yang terletak antara rentang 4,20 - 5,00 menunjukan bahwa pernyataan nomor 3 termasuk dalam kategori yang sangat baik.

Tabel 1. Analisis Deskriptif Variabel Strategi Promosi, Harga, Minat Beli dan Keputusan Pembelian

\begin{tabular}{|c|c|c|c|}
\hline No & Pernyataan & $\begin{array}{l}\text { Rata-Rata Per item } \\
\text { Pernyataan }\end{array}$ & Keterangan \\
\hline \multicolumn{4}{|c|}{ Strategi Promosi } \\
\hline $\mathrm{X} 11$ & Iklan Sasirangan Bordir Dimedia Massa dan Elektronik Sangat Menarik & 4,16 & Baik \\
\hline $\mathrm{X} 12$ & Iklan Mampu Menjangkau Semua Kalangan & 4,56 & Sangat Baik \\
\hline $\mathrm{X} 13$ & Ikaln Yang Dipromosikan Sesuai Dengan Kualitas Produk Yang Dijual & 4,32 & Sangat Baik \\
\hline \multicolumn{4}{|c|}{ Mean Variabel } \\
\hline \multicolumn{4}{|c|}{ Harga } \\
\hline $\mathrm{X} 21$ & Saya Membeli Kain Sasirangan Bordir Karena Harganya Terjangkau & 3,76 & Terjangkau \\
\hline $\mathrm{X} 22$ & Saya Membeli Kain Sasirangan Bordir Karena Sesuai Dengan Kualitasnya & 4,24 & $\begin{array}{c}\text { Sangat } \\
\text { Terjangkau }\end{array}$ \\
\hline $\mathrm{X} 23$ & Membeli Kain Sasirangan Bordir Karena sesuai dengan kemampuan saya & 4,32 & Sangat Terjangkau \\
\hline \multicolumn{4}{|c|}{$\begin{array}{ll} & \text { Mean Variabel } \\
\end{array}$} \\
\hline \multicolumn{4}{|c|}{ Minat Beli } \\
\hline Y11 & Saya lebih tertarik pada kain sasirangan bordir dibandingkan sasirangan yang lain & 3,84 & Berminat \\
\hline Y12 & Saya akan menyarankan orang lain untuk membeli kain sasirangan lain & 4,88 & Sangat Berminat \\
\hline Y13 & Saya mencari informasi tentang kain sasirangan bordir sebelum membelinya. & 3,78 & Berminat \\
\hline \multicolumn{4}{|c|}{ Mean Variabel } \\
\hline \multicolumn{4}{|c|}{ Keputusan Pembelian } \\
\hline Y21 & $\begin{array}{l}\text { Saya memutuskan untuk membeli kain sasirangan bordir setelah membandingkan } \\
\text { dengan kain sasirangan yang lain. }\end{array}$ & 3,85 & $\begin{array}{l}\text { Yakin Untuk } \\
\text { Membeli }\end{array}$ \\
\hline Y22 & $\begin{array}{l}\text { Saya membeli kain sasirangan bordir karena masih bersifat motif dan model yang } \\
\text { baru }\end{array}$ & 3,87 & $\begin{array}{l}\text { Yakin Untuk } \\
\text { Membeli }\end{array}$ \\
\hline Y23 & $\begin{array}{l}\text { Saya membeli kain sasirangan bordir karena jenis dan motif Yng ditawarkan sesuai } \\
\text { dengan kebutuhan. }\end{array}$ & 4,06 & $\begin{array}{l}\text { Yakin Untuk } \\
\text { Membeli }\end{array}$ \\
\hline \multicolumn{4}{|c|}{ Mean Variabel } \\
\hline
\end{tabular}

Sumber: Data diolah, 2020

\section{Deskripsi Variabel Harga}

Hasil pernyataan responden dan perhitungan nilai rata-rata pernyataan responden disetiap item pertanyaan variabel Harga dapat dilihat sebagai berikut:

Berdasarkan Tabel diatas menunjukan bahwa, jawaban responden mengenai Saya membeli kain sasirangan bordir karena harganya terjangkau berada pada skor jawaban 3,76 yang terletak antara rentang $3,40-4,19$ yang menunjukan bahwa pernyataan nomor 1 termasuk dalam kategori Terjangkau. Jawaban responden mengenai Saya membeli kain sasirangan bordir karena sesuai dengan kualitasnya berada pada skor jawaban 4,24 yang terletak antara rentang 4,20 - 5,00 menunjukan bahwa pernyataan nomor 2 termasuk dalam kategori sangat terjangkau. Sedangkan jawaban responden mengenai Saya membeli kain sasirangan borir karena sesuai dengan kemampuan saya berada pada skor jawaban 4,32 yang terletak antara rentang 4,20 - 5,00 menunjukan bahwa pernyataan nomor 3 termasuk dalam kategori yang sangat Terjangkau.

\section{Deskripsi Variabel Minat Beli}

Hasil pernyataan responden dan perhitungan nilai rata-rata pernyataan 
responden disetiap item pertanyaan variabel Minat Beli dapat dilihat sebagai berikut:

Berdasarkan Tabel diatas menunjukan bahwa, jawaban responden mengenai Saya lebih tertarik pada kain sasirangan bordir dibandingkan sasirangan yang lain berada pada skor jawaban 3,84 yang terletak antara rentang 3,40-4,19 yang menunjukan bahwa pernyataan nomor 1 termasuk dalam kategori bahwa konsumen tersebut berminat untuk membeli kain sasirangan bordir yang ditawarkan. Jawaban responden mengenai Saya akan menyarankan orang lain untuk membeli kain sasirangan lain berada pada skor jawaban 4,88 yang terletak antara rentang 4,20 - 5,00 menunjukan bahwa pernyataan nomor 2 termasuk dalam kategori bahwa konsumen tersebut sangat berminat untuk membeli kain sasirangan bordir yang ditawarkan. Sedangkan jawaban responden mengenai Saya mencari informasi tentang kain sasirangan bordir sebelum membelinya berada pada skor jawaban 3,78 yang terletak antara rentang 3,40 - 4,19 menunjukan bahwa pernyataan nomor 3 termasuk dalam kategori bahwa konsumen tersebut berminat untuk membeli kain sasirangan bordir yang ditawarkan.

\section{Keputusan Pembelian}

Hasil pernyataan responden dan perhitungan nilai rata-rata pernyataan responden disetiap item pertanyaan variabel Keputusan pembelian dapat dilihat pada sebagai berikut:

Berdasarkan Tabel diatas menunjukan bahwa, jawaban responden mengenai "Saya memutuskan untuk membeli kain sasirangan bordir setelah membandingkan dengan kain sasirangan yang lain" berada pada skor jawaban 3,85 yang terletak antara rentang 3,40 - 4,19 yang menunjukan bahwa pernyataan nomor 1 termasuk dalam kategori bahwa konsumen tersebut berminat untuk membeli kain sasirangan bordir yang ditawarkan. Jawaban responden mengenai Saya membeli kain sasirangan bordir karena masih bersifat motif dan model yang baru berada pada skor jawaban 3,87 yang terletak antara rentang 3,40 - 4,19 menunjukan bahwa pernyataan nomor 2 termasuk dalam kategori bahwa konsumen tersebut sangat berminat untuk membeli kain sasirangan bordir yang ditawarkan. Sedangkan jawaban responden mengenai Saya membeli kain sasirangan bordir karena jenis dan motif Yng ditawarkan sesuai dengan kebutuhan. berada pada skor jawaban 4,06 yang terletak antara rentang 3,40 - 4,19 menunjukan bahwa pernyataan nomor 3 termasuk dalam kategori bahwa konsumen tersebut berminat untuk membeli kain sasirangan bordir yang ditawarkan.

\section{Hasil Analisis Data}

Berdasarkan perhitungan regresi berganda antara Variabel strategi Promosi, Harga, Minat Beli dan Keputusan Membeli sekaligus akan dibuktikan apakah pengaruh yang diberikan merupakan pengaruh yang signifikan. Hasil uji regresi dapat dilihat pada tabel 2 .

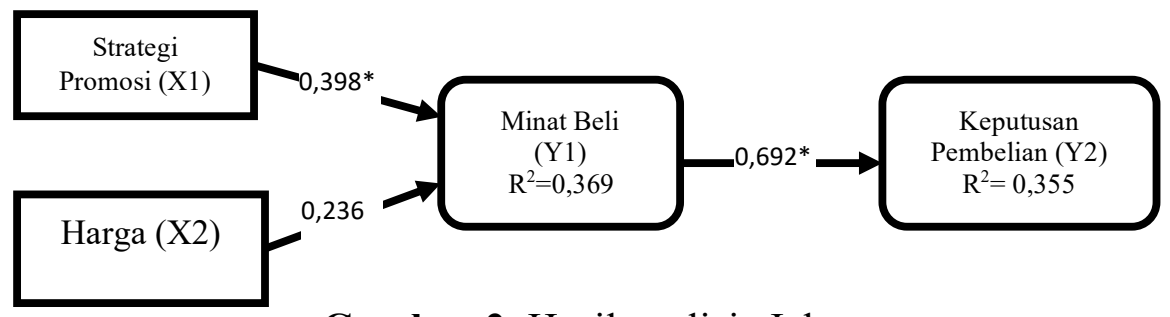

Gambar 2. Hasil analisis Jalur

Sumber: Data diolah, 2020

Tabel 2. Hasil Pengujian Analisis Jalur

\begin{tabular}{|l|l|l|l|l|l|l|l|}
\hline Uji & Hipotesis & $\mathbf{R}^{2}$ & Direct & Indirect & SE & $\mathbf{T}$ & Keterangan \\
\hline
\end{tabular}




\begin{tabular}{|l|lll|l|l|l|l|l|l|}
\hline 1 & $\begin{array}{l}\text { Strategi } \rightarrow \\
\text { Promosi }\end{array}$ & Minat Beli & 0.369 & 0.398 & - & 0.104 & 3.236 & Signifikan \\
\cline { 2 - 6 } & Harga $\rightarrow$ & Minat Beli & & 0.236 & - & 0.120 & 1.916 & $\begin{array}{l}\text { Tidak } \\
\text { Signifikan }\end{array}$ \\
\hline 2 & $\begin{array}{l}\text { Minat } \rightarrow \\
\text { Beli }\end{array}$ & $\begin{array}{l}\text { Keputusan } \\
\text { Pembelian }\end{array}$ & 0.355 & 0.692 & - & 0.081 & 9.479 & Signifikan \\
\hline 3 & $\begin{array}{l}\text { Strategi } \\
\text { Promosi }\end{array}$ & $\begin{array}{l}\text { Keputusan } \\
\text { Pembelian }\end{array}$ & 0.593 & - & 0.275 & 0.078 & 3.492 & Signifikan \\
\cline { 2 - 5 } & Harga $\rightarrow$ & $\begin{array}{l}\text { Keputusan } \\
\text { Pembelian }\end{array}$ & & - & 0.163 & 0.085 & 1.916 & $\begin{array}{l}\text { Tidak } \\
\text { Signifikan }\end{array}$ \\
\hline
\end{tabular}

Sumber: Data diolah, 2020

Uji ketepatan model untuk Model Keseluruhan adalah sebagai berikut:

$\mathrm{R}^{2}$ Overall Model $=1-\left(1-\mathrm{R}^{2}\right.$ Model 1$)\left(1-\mathrm{R}^{2}\right.$ Model 2$)$

$=1-(1-0.369)(1-0.355)$

$=1-(0.631)(645)$

$=1-0.407$

$=0.593$

Dari hasil analisis data yang telah dilakukan, hasil dari penelitian ini ditunjukkan pada Tabel 2 dan Persamaan 1. Tabel 1 menunjukkan bahwa pada pengujian pertama nilai kebaikan model sebesar 36.9 $\left(\mathrm{R}^{2}=0.369\right)$, dan pada pengujian model ke 2 menunjukkan kebaikan model sebesar $35.5 \%$ $\left(\mathrm{R}^{2}=0.355\right)$. Persamaan 1 menunjukkan bahwa model secara kesuluruhan pada pengujian ke tiga yang disusun memiliki kemampuan dalam menjelaskan keputusan pembelian yang dimediasi oleh minat beli sebesar $59.3 \%\left(\mathrm{R}^{2}\right.$ Overal model $\left.=0.593\right)$, dimana sisanya yaitu $40.7 \%$ dapat dijelaskan oleh variabel lain di luar penelitian ini.

Dari tabel 2 diketahui bahwa pada pengujian pertama menunjukkan pengaruh langsung strategi pemasaran dan harga terhadap minat beli. Dari hasil analisis diketahui bahwa strategi pemasaran dapat mempengaruhi minat beli sebesar 0.398 dimana hasil uji T menunjukkan nilai 3.236 (>1.96), sehingga dapat disimpulkan bahwa strategi promosi berpengaruh secara signifikan terhadap minat beli. Hasil dari variabel menunjukkan pengaruh terhadap minat beli sebesar 0.236 dimana nilai uji $\mathrm{T}$ menunjukkan hasil $1.916(<1.96)$, sehingga dapat disimpulkan bahwa variabel harga tidak berpengaruh signifikan terhadap minat beli. Pengujian ke dua menunjukkan bahwa secara langsung variabel minat beli dapat mempengaruhi variabel keputusan pembelian sebesar 0.692 dimana hasil uji $\mathrm{T}$ menunjukkan nilai sebesar 9.479 (>1.96), sehingga dapat disimpulkan bahwa secara langsung variabel minat beli dapat berpengaruh signifikan terhadap keputusan pembelian.

Hasil pengujian tidak langsung (Indirect) pada tabel 2 menunjukkan bahwa secara tidak langsung variabel strategi promosi yang dimediasi oleh minat beli berpengaruh terhadap keputusan pembelian sebesar 0.275, dimana hasil uji T menunjukkan nilai 3.492 (>1.96). Hal ini menunjukkan bahwa minat beli dapat secara signifikan me-mediasi pengaruh strategi promosi terhadap keputusan pembelian. Hasil pada variabel harga menunjukkan bahwa secara tidak langsung varibel harga yang di mediasi oleh minat beli terhadap keputusan pembelian menunjukkan hasil sebesar 0.163 dimana nilai uji $\mathrm{T}$ sebesar $1.916(<1.96)$. Hal ini menunjukkan bahwa minat beli tidak dapat secara signifikan me-mediasi pengaruh harga terhadap keputusan pembelian.

\section{Pembahasan}

Pengaruh Strategi Promosi Terhadap Minat beli Kain Sasirangan Bordir Bunga Bangkal

Pengaruh Strategi Promosi terhadap Minat membeli kain sasirangan border dalam penelitian ini dapat dibuktikan dengan Hasil nilai uji $-\mathrm{t}$ yakni sebesar 3.236 dan sig sebesar 0,000 . Dengan nilai diatas tingkat signifikansi $\alpha=<0,05$ maka menerima $\mathrm{H}_{\mathrm{a}}$ yang menyatakan strategi promosi berpengaruh signifikan terhadap minat membeli kain sasirangan border dengan nilai koefisien regresi bernilai positif sebesar 0,398, mempunyai arti bahwa jika strategi promosi semakin baik dimana variabel lain bersifat konstan, maka 
tingkat minat membeli yang dipengaruhi strategi promosi akan meningkat sebesar 0,398 atau $39.8 \%$. Dari hasil ini juga dapat diketahui bahwa strategi promosi memiliki nilai koefisien yang lebih besar pengaruhnya terhadap minat beli dibandingkan dengan harga.

\section{Pengaruh Strategi Promosi Terhadap Minat beli Kain Sasirangan Bordir Bunga Bangkal}

Pengaruh harga terhadap Minat membeli kain sasirangan border dalam penelitian ini dapat dibuktikan dengan Hasil nilai uji - $\mathrm{t}$ yakni sebesar 1.916 dan sig sebesar 0,540. Dengan nilai dibawah tingkat signifikansi $\alpha$ $=<0,05$ maka menerima $\mathrm{H}_{0}$ yang menyatakan strategi promosi tidak berpengaruh signifikan terhadap minat membeli kain sasirangan border dengan nilai koefisien regresi bernilai positif sebesar 0,236, mempunyai arti bahwa jika harga semakin meningkat dimana variabel lain bersifat konstan, maka tingkat minat membeli yang dipengaruhi strategi promosi akan meningkat sebesar 0,236 atau $23.6 \%$. Pada kasus ini, strategi harga yang dibuat mungkin tidak terlalu kompetitif dengan produsen lain, sehingga perbedaan harga tidak dirasakkan oleh semua responden.

\section{Pengaruh Minat Beli Terhadap Keputusan Pembelian Kain Sasirangan Bordir Bunga Bangkal.}

Pengaruh Minat beli terhadap keputusan membeli kain sasirangan border dalam penelitian ini dapat dibuktikan dengan Hasil nilai uji - t yakni sebesar 9.479 dan sig sebesar 0,000 . Dengan nilai diatas tingkat signifikansi $\alpha=<0,06$ maka menerima $\mathrm{H}_{\mathrm{a}}$ yang menyatakan minat beli berpengaruh signifikan terhadap tingkat keputusan membeli kain sasirangan border dengan nilai koefisien regresi) bernilai positif sebesar 0,692, mempunyai arti bahwa jika minat beli semakin meningkat satu satuan dimana variabel lain bersifat konstan, maka tingkat keyakinan akan keputusan membeli yang dipengaruhi minat membeli akan meningkat sebesar 0,692 atau $69.2 \%$.

\section{Pengaruh Strategi Promosi Terhadap Keputusan Pembelian Kain Sasirangan Bordir Bunga Bangkal.}

Promosi pada dasar adalah suatu komunikasi dalam pemasaran, artinya aktifitas pemasaran yang berusaha menyebarkan semua informasi, untuk mempengaruhi atau membujuk, mengingatkan pasar sasaran atas perusahaan dan produknya agar bersedia menerima, membeli dan loyal pada produk yang ditawarkan perusahaan yang bersangkutan.

Tujuan dari pada perusahaan melakukan promosi menurut Tjiptono (2001: 221) adalah menginformasikan mempengaruhi dan membujuk serta mengingatkan pelangggan tentang perusahaan dan bauran marketing pemasarannya. Setelah konsumen mengetahui produk yang baru, diharapkan konsumen akan dapat terpengaruh dan akan terbujuk sehingga dapat beralih ke produk yang ditawarkan dan pada akhirnya, perusahaan hanya sekedar mengingatkan bahwa produk tersebut tetap baik untuk dikonsumsi.

Hasil statistik uji regresi diperoleh berdasarkan hasil analisis bahwa t hitung sebesar 3,492 dengan nilai signifikans 0,002 , oleh karena nilai signifikansi lebih kecil dari $0,05 \quad(0,000<0,05)$, dan koefisien regresi mempunyai nilai positif sebesar 0,275; maka hipotesis yang menyatakan bahwa terdapat pengaruh strategi promosi terhadap keputusan pembelian yang dimediasi oleh minat beli kain sasirangan motif bordir terbukti. Besarnya pengaruh strategi promosi terhadap keputusan pembelian sebesar 0,275 hal ini berarti bahwa keputusan pembelian dipengaruhi oleh strategi promosi sebesar $27.5 \%$, sedangkan sisanya sebesar $72,5 \%$ dipengaruhi oleh faktor lain yang tidak termasuk dalam penelitian ini.

Pengaruh Harga Terhadap Keputusan Pembelian Kain Sasirangan Bordir Bunga Bangkal.

Pengaruh Variabel Harga terhadap keputusan membeli kain sasirangan border yang dimediasi oleh minat beli 
menunjukkan bahwa, hasil nilai uji - $\mathrm{t}$ antara harga sebesar 1.916 dan sig sebesar 0,058 . Dengan nilai diatas tingkat signifikansi $\alpha=<0,05$ maka menerima $\mathrm{H}_{0}$ yang menyatakan harga (X2) berpengaruh tidak signifikan terhadap minat membeli kain sasirangan bordir. Nilai koefisien beta dari harga bernilai positif sebesar 0,163, mempunyai arti bahwa jika strategi Harga diperbaiki, maka tingkat keyakinan membeli yang di intervening oleh minat membeli akan meningkat sebesar 0,163 atau $16,3 \%$. Hal ini berarti bahwa strategi harga yang ada bukanlah yang menjadi daya tarik utama, karena tidak semua responden merasakan adanya perbedaan harga yang signifikan antara objek penelitian dengan merek-merek lainnya.

\section{KESIMPULAN DAN SARAN}

Kesimpulan

Meskipun hasil penelitian menunjukkan ada pengaruh positif strategi promosi terhadap keputusan pembelian yang dimediasi oleh minat beli kain sasirangan bordir, akan tetapi perlu dilakukan evaluasi kegiatan promosi dan penetapan harga di tahun-tahun mendatang. Hal tersebut ditunjukkan oleh hasil dari strategi penetapan harga yang tidak terlalu berbeda jauh dengan competitor. Penetepan strategi harga memanglah hal yang cukup dilematis. Mengingat bahwa dalam penetapan harga ada kaidah-kaidah yang telah disepakati antar pengusaha kain sehingga tidak merusak harga pasaran terhadap competitor. Temuan dari penelitian ini juga menunjukkan bahwa hal yang lebih diperhatikan oleh konsumen adalah strategi pemasaran yang harus ditetapkan oleh pengusaha. Dengan membuat kemasan yang menarik, referensi aplikasi kain pada model pakaian, dan citra merek barangkali adalah hal yang lebih utama.
Dari hasil penelitian diketahui bahwa pengaruh secara tidak langsung strategi promosi dan harga terhadap keputusan memiliki tingkat kebaikan model sebesar $59.3 \%$, oleh karena itu, Pengelola kain sasirangan bordir bunga bangkal disarankan untuk selalu memantau harga yang telah ditetapkan, supaya semakin tepat dalam menentukan penetapan harga, sehingga keputusan pembelian konsumen semakinbaik dan meningkat.

Meskipun hasil penelitian menunjukkan ada pengaruh positif strategi promosidan harga terhadap keputusan pembelian yang dimediasi oleh minat beli kain sasirangan bordir, akan tetapi perlu dilakukan evaluasi kegiatan promosi dan penetapan harga di tahun-tahun mendatang.

Berdasarkan hasil penelitian diketahui bahwa pengaruh langsung strategi promosi dan harga terhadap keputusan pembelian sebesar 35,5\%, oleh karena itu, Pengelola kain sasirangan bordir bunga bangkal disarankan untuk selalu memonitoring harga yang ditetapkan, agar semakin tepat dalam menentukan penetapan harga, sehingga keputusan pembelian konsumen semakin tinggi.

\section{DAFTAR PUSTAKA}

Alma, Buchari, 2004, Manajemen Pemasaran Dan Pemasaran Jasa, edisi revisi, cetakan kelima, Penerbit : Alfabeta, Bandung.

Assauri, Sofjan. 2004. Manajeman Pemasaran. Raja Grafindo Persada. Jakarta.

Cannon, Joseph, dkk. 2009. Pemasaran Dasar. Jakarta: Salemba Empat.

Christian. 2011. Membangun Minat Beli. http:jurnalsdm.blogspot.com. Diakses tanggal 19 Desember 2012.

Ghozali, Imam. 2007. Aplikasi Analisis Multivariate dengan Program SPSS Edisi 4. Semarang: Badan Penerbit Universitas Diponegoro.

Hadi, Sutrisno. 2000. Metodologi Research. Yogyakarta: Andi Yogyakarta. 
Hartoto. 2009. Penelitian Deskriptif. http://www.penalaran-unm.org. Diakses pada tanggal 25 Desember 2012.

Kotler, Phillip. 1996. Principlesof Marketing. London, New York: Prentice Hall.

Kotler, Phillip. 2008. Manajemen Pemasaran Edisi Keenam Jilid 2. Jakarta: Erlangga.
Kotler, Philip dan Armstrong Gary. 2008. Prinsip-Prinsip Pemasaran Edisi Kedua Belas Jilid 2. Jakarta: Erlangga.

Kotler, Phillip dan Keller, Kevin. 2009. Manajemen Pemasaran Edisi Ketiga Belas Jilid 1. Jakarta: Erlangga.

Swastha, Basu dan T. Hani Handoko, 2000, Manajemen Pemasaran, Analisa Perilaku Konsumen, edisi pertama, cetakan ketiga, Penerbit : BPFE, Yogyakarta.

Schiffman \& Kanuk. 2004. Perilaku Konsumen edisi 7. Jakarta: Prentice Hall.

Swastha, Basu, 2008, Manajemen Pemasaran, Analisa Perilaku Konsumen, edisi pertama, cetakan keempat, Penerbit : BPFE, Yogyakarta

Sunyoto, Danang. 2012. Konsep Dasar Riset Pemasaran \& Perilaku Konsumen. Yogyakarta: CAPS.

Tjiptono, Fandy dan Gregorius Chandra, 2005, Service, Quality dan Satisfaction, edisi pertama, cetakan kedua, Penerbit : ANDI, Yogyakarta.

Umar, Husein. 2003. Metode Riset Bisnis. Jakarta : PT Gramedia Pustaka. Utampa 